\title{
Duration of overgrowth affects survival of encrusting coralline algae
}

\author{
Fabio Bulleri* \\ Centro Interdipartimentale di Ricerca per le Scienze Ambientali in Ravenna, and \\ Dipartimento di Biologia Evoluzionistica e Sperimentale, Università di Bologna, Ravenna 48100, Italy \\ Present address: Dipartimento di Biologia, Università di Pisa, Via A. Volta 6, 56126 Pisa, Italy
}

\begin{abstract}
Encrusting algae can withstand being overgrown for relatively long periods of time. Knowledge of the mechanisms operating to reduce loss of biomass and of the temporal scales over which these are efficient is crucial for understanding competitive interactions occurring via overgrowth. In some red encrusting algae, the translocation of metabolites from unshaded to shaded parts of the thallus has been indicated as a possible mechanism for their resistance to overgrowth. This study tested the hypothesis that the efficacy of the connection between shaded and unshaded portions of the thallus in promoting the survival of the encrusting coralline alga Neogoniolithon brassicaflorida, when overgrown, would vary according to the duration of the overgrowth. This hypothesis was tested experimentally by manipulating the availability of light and the connection between shaded and unshaded parts of the thalli. Although there was a slightly different response between experimental trials, the connection with unshaded parts enhanced the survival of shaded parts of the thallus, over a period of about $3 \mathrm{mo}$. In contrast, $8 \mathrm{mo}$ after the start of the experiment, the percentage cover of living $N$. brassica-florida under artificial shading devices was small, irrespective of the presence or absence of a connection with unshaded parts of the thallus. These results support the model that translocation of nutrients across the thallus could enable encrusting algae to survive being overgrown, but not indefinitely. This study underpins the need to take into account life-history traits of interacting species when interpreting competition occurring via overgrowth.
\end{abstract}

KEY WORDS: Encrusting algae $\cdot$ Overgrowth $\cdot$ Competition $\cdot$ Subtidal $\cdot$ Rocky reefs

\section{INTRODUCTION}

Competition for space is an important determinant of patterns of abundance and distribution of marine organisms on rocky substrata (Dayton 1971, Paine 1984). Sessile marine organisms must acquire and defend space in order to gain access to plankton or nutrients from the water column, or light for photosynthesis. Interference competition (sensu Miller 1967) among sessile marine organisms, either macroalgae or invertebrates, often occurs via overgrowth (Jackson 1977, Buss \& Jackson 1979). A variety of mechanisms can be involved in the process of overgrowth, including direct chemical and physical aggression (Jackson
\& Buss 1975, Sebens 1984), bulldozing and smothering (Connell 1961, Dayton 1971), depletion of food sources (Buss 1979) and shading of photosynthetic organisms (Dayton 1975, Sebens 1986). Overgrowth does not, however, necessarily imply the definitive displacement of competitively subordinate organisms (Sebens 1986, Miles \& Meslow 1990, Airoldi 2000, Dethier \& Steneck 2001, Underwood 2006).

Red encrusting algae have been described as poor competitors for space (Breitburg 1984), but they are able to tolerate burial in sediments or overgrowth by erect algal forms and invertebrates for relatively long periods of time (Sebens 1986, Steneck 1986, Miles \& Meslow 1990, Kendrick 1991, Dethier 1994, Airoldi 
2000, Dethier \& Steneck 2001, Underwood 2006). Indeed, positive effects of epiphytes and canopy algae on the survival of encrusting corallines through amelioration of physical conditions (i.e. desiccation and light intensity) have been documented in intertidal and shallow subtidal rocky habitats (Figueiredo et al. 2000, Melville \& Connell 2001, Irving et al. 2004).

The response of encrusting coralline algae to overgrowth is, to some extent, correlated to the degree of physiological integration of the thallus (Dethier \& Steneck 2001). Although still debated, several morphological features are implied in the transfer of metabolites among different parts of the thallus, including cell fusion, primary and secondary pits and a hypothallus directed laterally (Wetherbee 1979, Steneck 1986, Dethier \& Steneck 2001). For example, Dethier \& Steneck (2001) suggested that Lithothamnion phymatodeum could resist overgrowth because of abundant cell fusion, facilitating the movement of photosynthates across the thallus, while Lithophyllum impressum, lacking structures capable of transporting metabolites (no cell fusion and small hypothallus), suffered overgrowth (Dethier \& Steneck 2001).

Recently, Underwood (2006) has experimentally shown that the connection between shaded and unshaded portions of the thallus enables the intertidal red encrusting alga Hildenbrandia rubra to withstand being overgrown for a long period of time (13 mo).

A comprehensive understanding of the ecological implications of resistance to overgrowth by encrusting algae can, however, only be achieved by determining

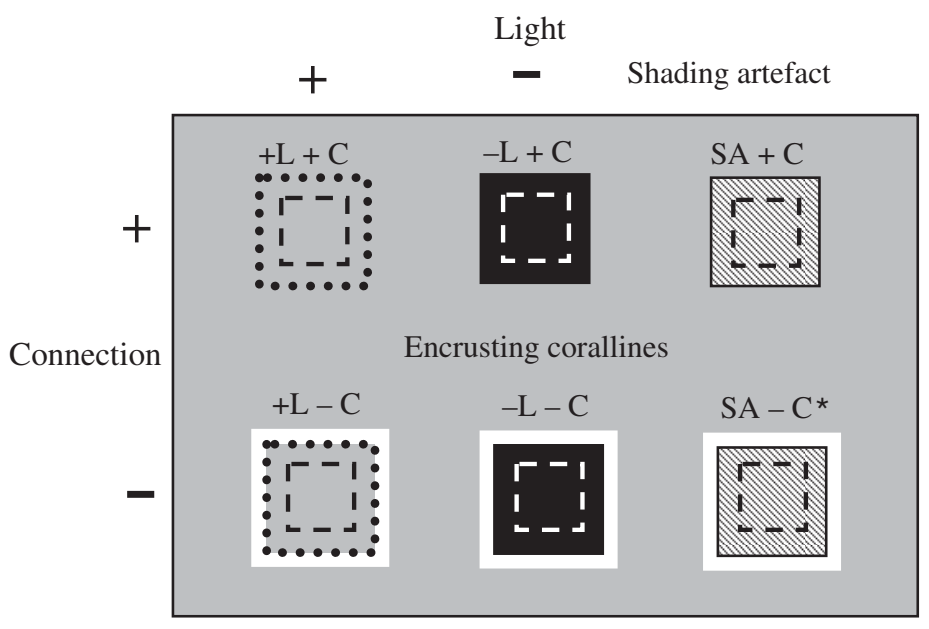

Fig. 1. The 6 experimental treatments originated by the orthogonal manipulation of connection (2 levels: + and -) and light (3 levels:,+- and shading artefact). The inner dashed lines represent the surface sampled. Grey quadrats: no plastic sheet; black quadrats: black plastic sheets; hatched quadrats: transparent plastic sheets; L: light; C: connection; SA: shading artefact. *: treatment not included in the second run of the experiment how long they can survive being overgrown. This study was, therefore, designed to identify the temporal scales over which the connection between shaded and unshaded portions of the thallus could be effective in preventing or reducing loss of biomass in encrusting coralline algae. Specifically, I aimed to test the hypothesis that the importance of the connection between shaded and unshaded portions of the thallus would vary according to the length of the exposure to experimental shading. The encrusting coralline alga Neogoniolithon brassica-florida (Harvey) Setchell \& Mason was chosen because it is characterised by the presence of cell fusions (Cabioch 1971) that supposedly enable exchange of material across different portions of the thallus.

\section{MATERIALS AND METHODS}

This study was done on shallow rocky reefs south of the town of Livorno, on the north-west coast of Italy $\left(43^{\circ} 30^{\prime} \mathrm{N}, 10^{\circ} 20^{\prime} \mathrm{E}\right)$. Intense grazing by the sea urchins Paracentrotus lividus and Arbacia lixula near their refuges (cracks or crevices) results in the formation of patches dominated by the encrusting coralline alga Neogoniolithon brassica-florida within stands of turfforming algae (Benedetti-Cecchi et al. 1998, Bulleri et al. 1999, 2002). In these patches, coalescing crusts form a homogeneous layer, interrupted by relatively small areas of bare rock ( 1 to $5 \mathrm{~cm}^{2}$; F. Bulleri pers. obs.), or areas of bleaching or overgrowth (e.g. by Peyssonnelia sp.).

In March 2003, 18 patches dominated by Neogoniolithon brassica-florida, ranging from 2 to $5 \mathrm{~m}^{2}$, were identified on horizontal or gently sloping surfaces, at depths of 2 to $3 \mathrm{~m}$. Subsets of 3 patches were randomly allocated to each of 6 treatments (Fig. 1), produced by crossing the factors light (3 levels: + light, - light, shading artefact) and connection (2 levels: connected vs. not connected), as required to test my hypothesis. In each patch, 4 randomly identified $10 \times 10 \mathrm{~cm}$ quadrats were marked at the corners with marine epoxy putty (Veneziani Subcoat). Since it was not always possible to distinguish individual crusts in the field, it is likely that $>1$ thallus was included inside marked quadrats. Where necessary, quadrats were isolated from contiguous encrusting corallines by chiselling a $4 \mathrm{~cm}$ wide border along their perimeter (Fig. 1). Recolonisation of these borders through recruitment from the water column or lateral expansion of surrounding crusts was prevented by scraping the substratum at monthly intervals. Artificial shading was obtained using $13 \times 13$ $\times 0.5 \mathrm{~cm}$ black Plexiglas sheets that were fixed about $5 \mathrm{~mm}$ above the quadrats by means of stainless steel screws plugged in holes drilled in the substratum (Fig. 1). In the case of quadrats not connected to sur- 
rounding crusts, half of the chiselled border $(2 \mathrm{~cm})$ was included under the plastic sheet. Foam rubber pads (polystyrene, $1 \mathrm{~cm}$ wide), glued to the borders of Plexiglas sheets, moulding to the contour of the substratum, increased the efficiency of these devices in blocking light. Since rubber pads were fixed on the borders of the plastic sheets, they did not apply any physical pressure on the inner surface, but likely prevented a regular flux of water, as happens with natural overgrowth. Transparent sheets of the same size and with foam rubber pads glued at their borders were used to test for potential artefacts of experimental shading and alteration in the flux of water (Fig. 1). Epiphytes (mainly filamentous algae) were removed from the transparent sheets every 2 wk using a plastic brush. The accumulation of sediment under the plastic sheets was generally negligible. Sea urchins could not access encrusting corallines after plastic sheets were deployed, whilst they could graze freely within quadrats assigned to the + light treatment. In order to prevent the effects of manipulative conditions on encrusting corallines being confounded with those of differential grazing pressure, sea urchins were removed from the experimental patches during $2 \mathrm{wk}$ visits in the field. According to the results of previous studies, showing that the physical transplant (Airoldi 2000) or the scraping/cutting of plants (Underwood 2006) did not affect the survival of red encrusting algae, controls for artefacts of disconnecting portions of thalli were not incorporated in the experimental design. A $2 \mathrm{~cm}$ wide external border was, however, not included in the sampling, in order to minimise potential artefacts of cutting edges and effects of residual penetration of light caused by partial adherence of shading devices to irregularities of the bottom (e.g. pits, crack, ridges).

Unfortunately, most of the panels were ripped off the substratum by a large swell hitting the coast shortly after the first sampling $(3 \mathrm{mo})$, so that the first experimental trial had to be terminated. The experiment was repeated in July 2003. Since the analysis of data for the first start of the experiment indicated no significant artefact effects of experimental shading (see 'Results'), only the combination shading artefact-connected was maintained in the second trial (Fig. 1). A new set of 25 patches dominated by Neogoniolithon brassica-florida was selected at random from those available. Each of the 5 treatments was, therefore, replicated in 5 patches, to increase chances of running the experiment for a longer period of time in the face of loss of experimental units caused by storm damage. Occasionally, some panels were dislodged by storms, but these were readily replaced when sea conditions improved, so that treatments were adequately maintained throughout the duration of the study in all of the experimental patches.
The percentage cover of encrusting corallines was estimated in the inner $8 \times 8 \mathrm{~cm}^{2}$ of marked quadrats before the start of the experiment to check for a priori differences among treatments and then after 3 and $8 \mathrm{mo}$. Bleached (pale white) encrusting corallines were considered dead when flaking off the substratum, or when they could be removed through light scraping of the surface. Quadrats were sampled visually, using a plastic frame divided into 25 sub-quadrats and giving a score from 0 to $4 \%$ to each of them. Final cover was obtained by summing over the 25 sub-quadrats (Dethier et al. 1993).

The percentage cover of encrusting corallines before initiation of the experiments was compared among treatments by 2-factor ANOVAs, including the factors treatment (fixed) and patch (random and nested within treatment). The response of encrusting corallines to the manipulation, 3 and 8 mo after the experiments were started, was analysed by means of 3-factor ANOVAs, including the factors connection (fixed), light (fixed and crossed) and patch (random and nested within the interaction connection $\times$ light). For the second experimental trial, the percentage cover of encrusting corallines was separately compared between + lightconnected and shading artefact-connected quadrats, to test for the effects of artefacts due to shading devices. Furthermore, data collected after 3 and 8 mo in the second experiment were analysed separately, because they were not independent through time (the same quadrats were sampled at each time).

Data relative to 3 mo after each of the experiments was started were also analysed using exactly the same ANOVA model (treatments and numbers of replicates), in order to assess whether inconsistencies between trials (see 'Results') were caused by the use of a different experimental design or, alternatively, reflected real variation in the response of encrusting corallines to manipulative conditions. The analysis included the factors connection (2 levels: + or -), light (2 levels: + and -) and patch ( 3 levels; data from 2 randomly chosen patches were discarded for the second experiment).

Cochran's test was used to check for heterogeneity of variances and, when appropriate, Student-NewmanKeuls (SNK) tests were performed for a posteriori comparisons of the means (Winer et al. 1991, Underwood 1997).

\section{RESULTS}

The percentage cover of encrusting corallines did not differ among treatments before the experiments were initiated, but there was large variability among patches (Figs. $2 \& 3$, Table 1). Three months after the first experiment was initiated, there was a significant 


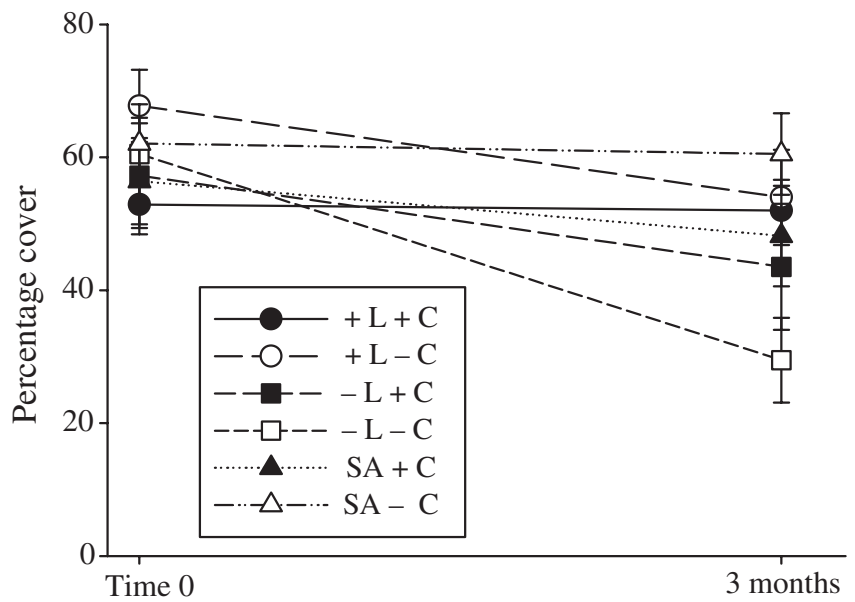

Fig. 2. Neogoniolithon brassica-florida. First run of the experiment (March 2003). Mean percentage cover ( \pm SE) of living coralline algae in quadrats assigned to the different treatments, before (Time 0) and 3 mo after the experiment was started. L: light; C: connection; SA: shading artefact $(\mathrm{n}=12$, data pooled across patches)

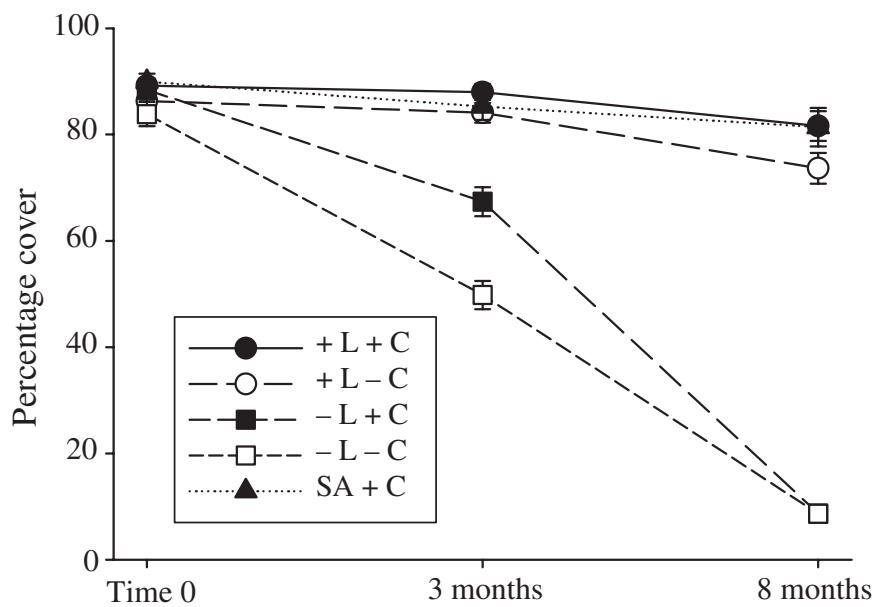

Fig. 3. Neogoniolithon brassica-florida. Second run of the experiment (July 2003). Mean percentage cover $( \pm$ SE) of living coralline algae in quadrats assigned to the different treatments, before (Time 0), 3 and 8 mo after the experiment was started. L: light; C: connection; SA: shading artefact $(n=20$, data pooled across patches)

decrease in the percentage cover of encrusting corallines in shaded conditions (Fig. 2, Table 2). Although there was a tendency for the mortality of encrusting corallines to be greater in shaded conditions when not connected with surrounding portions of thalli receiving sunlight, the analysis did not show significant effects of connection. The percentage cover of encrusting corallines did not differ between + light and shading artefact treatments (either connected or not connected), indicating no artefacts of experimental shading devices (Fig. 2, Table 2).
Three months after the second experiment was initiated, shading caused a decrease in the percentage cover of encrusting corallines, which was greater when these where not connected with unshaded portions of thalli (Fig. 3, Table 3). In contrast, the percentage cover of encrusting corallines dropped to very small amounts in shaded quadrats after $8 \mathrm{mo}$, irrespective of the presence or absence of a connection with unshaded portions of the thalli (Fig. 3, Table 3). At both times of sampling, there was no significant difference between + light-connected and shading artefact-connected (3 mo: $\mathrm{MS}=75.625 ; F_{1,8}=0.68, \mathrm{p}>0.05 ; 8 \mathrm{mo}: \mathrm{MS}=$ $\left.0.400 ; F_{1,8}=0.00, \mathrm{p}>0.05\right)$, indicating no artefact effect of experimental shading devices (Fig. 3). Variability among patches was large after 3 but not 8 mo after the start of the experiment (Table 3).

The results of the analysis, including the same treatments and numbers of replicates performed on data relative to 3 mo after each experimental trial was started, were in agreement with those obtained using different designs (reported in Tables 2 \& 3). In fact, there was a significant effect of light (MS $=10830.02$, $F_{1,8}=55.67, \mathrm{p}<0.001$, tested on patch [connection $\times$ light], MS = 194.54) and of the interaction connection $\times$ light $\left(\mathrm{MS}=972.00, F_{1,8}=6.00, \mathrm{p}<0.05\right.$, tested on patch [connection $\times$ light], $\mathrm{MS}=162.06$ ) for the first and second experimental trial, respectively. As shown for patches, the variation among replicate quadrats did not differ much between experimental trials either (Expt 1: MS = 66.09; Expt 2: MS = 77.83).

\section{DISCUSSION}

Over a 3 mo period of shading, physical disconnection from photosynthetically active portions of the thallus generally resulted in a marked decrease in the cover of Neogoniolithon brassica-florida, compared to patches left connected to unshaded thalli. These results are in agreement with those of Underwood (2006) and support the model that re-distribution of metabolites from uncovered to shaded portions of the thallus could be responsible for the ability of red algal crusts to resist overgrowth (Wetherbee 1979, Steneck 1983, 1986). Although this study does not provide definitive experimental evidence of the specific mechanism operating, physiological integration of the thallus in $N$. brassicaflorida could stem from the rapid formation of cell fusions (Cabioch 1971).

Although the short-term response (3 mo) of coralline crusts to manipulative conditions showed a similar trend in the 2 experimental trials, negative effects of disconnecting shaded and unshaded portions of the thallus for the first run of the experiment were not clear-cut. Unfortunately, the use of different experi- 
Table 1. Neogoniolithon brassica-florida. Comparison of the percentage cover of living coralline algae among treatments and patches before the experiments were started, in March and July 2003. Degrees of freedom for July 2003 are reported in brackets. ${ }^{* *} \mathrm{p}<0.01 ;{ }^{* * *} \mathrm{p}<0.001$

\begin{tabular}{|c|c|c|c|c|c|}
\hline \multirow{2}{*}{ Source of variation } & \multirow{2}{*}{ df } & \multicolumn{2}{|c|}{ March 2003} & \multicolumn{2}{|c|}{ July 2003} \\
\hline & & MS & $F$ & MS & $F$ \\
\hline Treatment $=\mathrm{T}$ & $5(4)$ & 320.74 & 0.86 & 122.29 & 0.74 \\
\hline Patch $(\mathrm{T})$ & $12(20)$ & 372.75 & $3.37^{* *}$ & 165.01 & $4.47^{* * *}$ \\
\hline Residual & $54(75)$ & 110.58 & & \multicolumn{2}{|l|}{36.95} \\
\hline Cochran's test & \multicolumn{3}{|c|}{$C=0.18, p>0.05$} & \multirow{2}{*}{\multicolumn{2}{|c|}{$C=0.15, \mathrm{p}>0.05$}} \\
\hline Transformation & & \multicolumn{2}{|c|}{$\begin{array}{l}\text { None } \\
\text { Non }\end{array}$} & & \\
\hline
\end{tabular}

Table 2. Neogoniolithon brassica-florida. Analysis of the effects of connection (connected vs. not connected), light $(+,-$ and shading artefact) and patch on the percentage cover of living coralline algae after 3 mo from the start of the first experiment (March 2003). ${ }^{* *} \mathrm{p}<0.01$; SNK: Student-Newman-Keuls)

\begin{tabular}{|c|c|c|c|c|}
\hline Source of variation & $\mathrm{df}$ & MS & $F$ & Denominator \\
\hline Connection $=\mathrm{C}$ & 1 & 6.12 & 0.02 & Patch $(\mathrm{L} \times \mathrm{C})$ \\
\hline Light $=\mathrm{L}$ & 2 & 2248.26 & $8.80^{* *}$ & Patch $(\mathrm{L} \times \mathrm{C})$ \\
\hline $\mathrm{C} \times \mathrm{L}$ & 2 & 509.04 & 1.99 & Patch $(\mathrm{L} \times \mathrm{C})$ \\
\hline Patch $(\mathrm{C} \times \mathrm{L})$ & 12 & 255.61 & 1.15 & Residual \\
\hline Residual & 54 & 222.30 & & \\
\hline Cochran's test & & $C=0.16, \mathrm{p}>0.05$ & & \\
\hline Transformation & & None & & \\
\hline \multicolumn{5}{|l|}{ SNK tests $(\mathrm{SE}=3.26)$} \\
\hline Light: Shading artef & $+\mathrm{Li}$ & $>-$ Light & & \\
\hline
\end{tabular}

Table 3. Neogoniolithon brassica-florida. Analysis on the effects of connection (connected vs. not connected), light (+ and -) and patch on the percentage cover of living coralline algae after 3 and 8 mo from the start of the second experiment (July 2003). ${ }^{*} \mathrm{p}<0.05 ;{ }^{* *} \mathrm{p}<0.01 ;{ }^{* * *} \mathrm{p}<0.001$; SNK: Student-Newman-Keuls

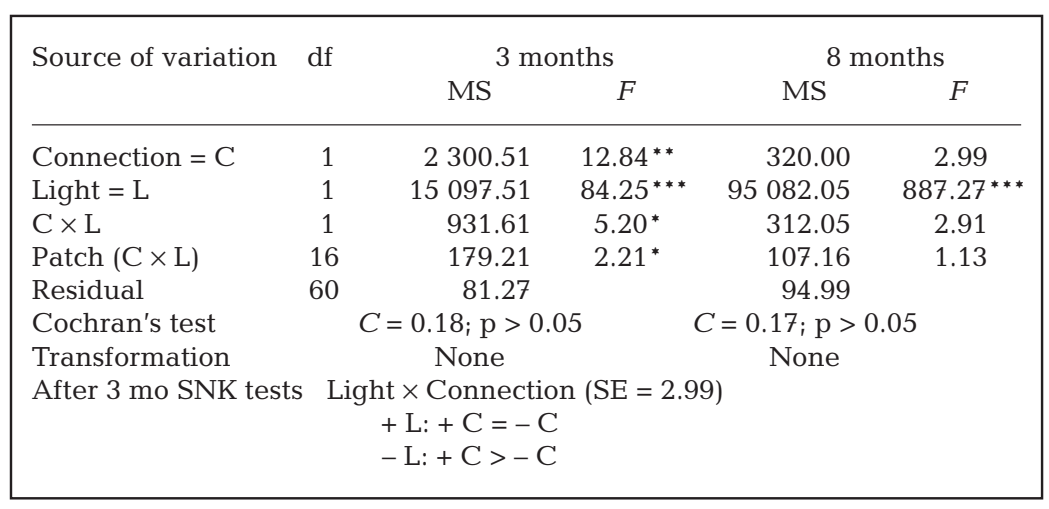

quadrats (see Tables $2 \& 3$ ), did not account for the variation between experimental trials. This would suggest that the ability of the algal crust to survive when overgrown could vary among different times of the year. Dethier \& Steneck (2001) observed 2 different responses of algal crusts to escape overgrowth: (1) supply of nutrients from uncovered to overgrown portions of thallus and (2) accelerating growth of unshaded margins. Due to the coalescence of thalli, external uncovered margins of crusts were not identifiable and their growth could not be quantified in this study, preventing the assessment of whether weak positive effects of connection on shaded portions of the thallus were compensated for by greater growth of unshaded margins.

The strong decline in the cover of living crusts under shaded conditions after $8 \mathrm{mo}$, despite the connection with uncovered portions, suggests that the effectiveness of translocation of metabolites as a mechanism to survive overgrowth is limited through time. These results are in contrast with previous studies, showing that red algal crusts can persist under shading conditions for longer periods of time (Sebens 1986, Steneck 1986, Miles \& Meslow 1990, Kendrick 1991, Dethier 1994, Airoldi 2000, Dethier \& Steneck 2001, Underwood 2006). Nonetheless, large variation among species can be expected, according to the efficacy of anatomical features of the thallus in providing physiological integration (Dethier \& Steneck 2001). Furthermore, variation among species in the temporal extent to which overgrowth can be tolerated could be due to differences in the storage of nutrients. For example, Underwood (2006) recorded considerable survival of Hildenbrandia rubra in dark conditions, even in the ab-

mental designs prevents a definitive assessment of the nature of the variation between experimental trials. Nonetheless, when data from the 2 experiments were analysed with the same ANOVA model, significant effects of the factor light and of the interaction connection $\times$ light were still evident for the first and second experiment, respectively. Hence, the use of different experimental designs, although affecting the precision of estimates of variation among patches and replicate sence of connection to unshaded thallus, and has argued that these portions of the alga would likely succumb, but the process would take a very long time. Here, limited resistance to overgrowth by Neogoniolithon brassicaflorida suggests that the physiological integration of the thallus, due to the presence of cell fusions (Cabioch 1971), is not as efficient as in other red encrusting algae (e.g. H. rubra; Underwood 2006) and also that the availability of stored nutrients is limited. 
The reduction of light intensity by algal canopies has been proven to play a key role in the persistence of encrusting corallines in shallow rocky reefs (Melville \& Connell 2001, Connell 2003, Irving et al. 2004). The removal of organisms providing shade can result in the rapid bleaching of understorey encrusting corallines (Figueiredo et al. 2000, Melville \& Connell 2001, Connell 2003). Facilitative effects of shading do not, however, imply that encrusting corallines are able to thrive indefinitely in dark conditions. Although logistical constraints prevented its measurement beneath the dark plastic sheets used in this study (plastic sheets were almost flush with the substratum), the level of light intensity was likely to have been much lower than that beneath epiphytes, such as turfing or canopyforming algae (Steneck \& Paine 1986, Kendrick 1991, Airoldi 2000, Melville \& Connell 2001). The negative effects of overgrowth by the sessile organisms blocking most of the light (e.g. invertebrates or holdfasts of plants) could also be counterbalanced by their protection from grazers or supply of nutrients (Sebens 1986).

The ability of algal crusts to survive dark conditions can be suspected to be dependent upon the ratio between the proportion of the thallus suffering overgrowth and that receiving light. Reasonably, a small amount of the thallus left uncovered should not be able to support indefinitely large shaded portions. Dethier $\&$ Steneck (2001) shaded an average of $78 \%$ of the surface of algal crusts and recorded, for some species, considerable survival after $1 \mathrm{yr}$. In the present study, due to the tendency of the algal crust to form a homogeneous cover in over-grazed patches, the proportion of shaded versus unshaded parts of the thallus could not be controlled or even standardised. The size of crusts exposed to artificial overgrowth by Dethier \& Steneck (2001) was smaller (60 to $800 \mathrm{~mm}^{2}$ ) than that of crusts in the present study, and, importantly, changes in the cover of living crusts were assessed over the entire shaded portion. Similarly, the survival of encrusting corallines under the large rubber pads $(42 \times$ $42 \mathrm{~cm})$, mimicking kelp holdfasts used by Miles \& Meslow (1990), was evaluated over the entire shaded surface. Here, the response of algal crusts was quantified only within the inner $8 \times 8 \mathrm{~cm}^{2}$ of the quadrats, leaving an external $2 \mathrm{~cm}$ wide margin, in order to avoid the effects of residual penetration of light under shading devices. As a consequence, the support of portions of crusts not able to photosynthesise implied a shift of nutrients across a considerable distance. Although positive effects of connection after 3 mo show that there was, to some extent, physiological integration of shaded and unshaded portions of thalli of algal crusts, it could be hypothesised that the efficacy of lateral translocation of metabolites would decrease as the distance between the shaded and the photosynthetically active portions of the thallus increased. In theory, minimisation of the ratio area/ perimeter in thalli of algal crusts should enhance resistance to overgrowth, by reducing the distance over which metabolites must be translocated. As suggested by Underwood (2006), further experimental work is needed to understand how the response of algal crusts varies according to the severity (amount of surface) of overgrowth and to the shape of the thallus.

Rapid recolonisation of space through recruitment and wound healing, rather than maintenance of occupied space through lateral expansion, has been indicated as the main determinant of the persistence of encrusting algal forms in low intertidal and shallow subtidal habitats (Adey \& Vassar 1975, Dethier 1981, 1994, Figueiredo et al. 1997, Kaehler \& Williams 1997, Airoldi 2000, Dethier \& Steneck 2001). The ability of algal crusts to withstand overgrowth, although limited to a relatively short period of time, could, however, have important ecological implications. Encrusting algae are less susceptible than other components of algal assemblages of shallow rocky reefs to a variety of disturbances other than overgrowth, including sedimentation, sand scour and grazing (Steneck 1986, Airoldi 2000, Bulleri et al. 2002). The temporal scales over which translocation of metabolites from unshaded to shaded portions of the thallus is effective in preventing loss of biomass could, therefore, exceed scales of variation in overgrowth. Under these circumstances, the inability to resist long periods of overgrowth could be unimportant for encrusting algae to hold space consistently through time. Finally, although the amount of time over which encrusting algae can tolerate overgrowth is likely to vary greatly among species (Dethier \& Steneck 2001, Underwood 2006, present study), this study suggests that life-history traits of interacting species should be taken into account when making inferences about the outcomes of competition occurring via overgrowth.

Acknowledgements. Many thanks are due to M. Abbiati, L. Airoldi, L. Benedetti-Cecchi, M. G. Chapman and A. J. Underwood for insightful and stimulating discussions, to G. Sartoni and G. Bressan for identification of the encrusting coralline algae and to $\mathrm{M}$. Carrera for sharing the hard work in the field. Two anonymous reviewers greatly improved the final version of this manuscript. This study was funded through the project COFIN (ex $40 \%$ ) to M. Abbiati.

\section{LITERATURE CITED}

Adey WH, Vassar JR (1975) Colonization, succession and growth rates of tropical crustose coralline algae (Rhodophyta, Cryptonemiales). Phycologia 14:55-69

Airoldi L (2000) Effects of disturbance, life-histories, and overgrowth on coexistence of algal crusts and turfs. Ecology 81:798-814

Benedetti-Cecchi L, Bulleri F, Cinelli F (1998) Density dependent foraging of sea urchins in shallow subtidal reefs on 
the west coast of Italy (western Mediterranean). Mar Ecol Prog Ser 163:203-211

Breitburg DL (1984) Residual effects of grazing: inhibition of competitor recruitment by encrusting coralline algae. Ecology 65:1136-1143

Bulleri F, Benedetti-Cecchi L, Cinelli F (1999) Grazing by the sea urchins Arbacia lixula L. and Paracentrotus lividus Lam. in the northwest Mediterranean. J Exp Mar Biol Ecol 241:81-95

Bulleri F, Bertocci I, Micheli F (2002) Interplay of encrusting coralline algae and sea urchins in maintaining alternative habitats. Mar Ecol Prog Ser 243:101-109

Buss LW (1979) Bryozoan overgrowth interactions - the interdependence of competition for space and food. Nature 281:475-477

Buss LW, Jackson JBC (1979) Competitive networks: nontransitive competitive relationships in cryptical coral reef environments. Am Nat 113:223-234

Cabioch J (1971) Etude sur les Corallinacées. I. Caractères généraux de la cytologie. Cah Biol Mar 12:121-186

Connell JH (1961) Effects of competition, predation by Thais lapillus and other factors on natural populations of the barnacle Balanus balanoides. Ecol Monogr 31:61-104

Connell SD (2003) The monopolization of understorey habitat by subtidal encrusting coralline algae: a test of the combined effects of canopy-mediated light and sedimentation. Mar Biol 142:1065-1071

Dayton PK (1971) Competition, disturbance and community organization: the provision and subsequent utilization of space in a rocky intertidal community. Ecol Monogr 41: 351-389

Dayton PK (1975) Experimental evaluation of ecological dominance in a rocky intertidal community. Ecol Monogr 45: 137-159

Dethier MN (1981) Heteromorphic algal life histories: the seasonal pattern and response to herbivory of the brown crust, Ralfsia californica. Oecologia 49:333-339

Dethier MN (1994) The ecology of intertidal algal crusts: variation within a functional group. J Exp Mar Biol Ecol 177: $37-71$

Dethier MN, Steneck RS (2001) Growth and persistence of diverse intertidal crusts: survival of the slow in a fastpaced world. Mar Ecol Prog Ser 223:89-100

Dethier MN, Graham ES, Cohen S, Tear LM (1993) Visual versus random-point percent cover estimations: 'objective' is not always better. Mar Ecol Prog Ser 110:9-18

Figueiredo MA de O, Norton TA, Kain JM (1997) Settlement and survival of epiphytes on two intertidal crustose coralline algae. J Exp Mar Biol Ecol 213:247-260

Figueiredo MA de O, Kain JM, Norton TA (2000) Responses of crustose corallines to epiphyte and canopy cover. J Phycol 36:17-24

Editorial responsibility: Roger N. Hughes (Contributing Editor), Bangor, UK
Irving AD, Connell SD, Elsdon TS (2004) Effects of kelp canopies on bleaching and photosynthetic activity of encrusting corallines. J Exp Mar Biol Ecol 310:1-12

Jackson JBC (1977) Competition on marine hard substrata: the adaptive significance of solitary and colonial strategies. Am Nat 111:743-768

Jackson JBC, Buss LW (1975) Allelopathy and spatial competition among coral reef invertebrates. Proc Natl Acad Sci USA 72:5160-5163

Kaehler S, Williams GA (1997) Do factors influencing recruitment ultimately determine the distribution and abundance of encrusting algae on seasonal tropical shores? Mar Ecol Prog Ser 156:87-96

Kendrick GA (1991) Recruitment of coralline crusts and filamentous turf algae in the Galapagos Archipelago: effect of simulated scour, erosion and accretion. J Exp Mar Biol Ecol 147:47-63

Melville AJ, Connell SD (2001) Experimental effects of kelp canopies on subtidal coralline algae. Aust Ecol 26:102-108

Miles KA, Meslow EC (1990) Effects of experimental overgrowth on survival and change in the turf assemblage of a giant kelp forest. J Exp Mar Biol Ecol 135:229-242

Miller RS (1967) Pattern and process in competition. Adv Ecol Res $4: 1-74$

Paine RT (1984) Ecological determinism in the competition for space. Ecology 65:1339-1348

Sebens KP (1984) Agonistic behavior in the intertidal seaanemone Anthopleura xanthogrammica. Biol Bull (Woods Hole) 166:457-472

Sebens KP (1986) Spatial relationships among encrusting marine organisms in the New England subtidal zone. Ecol Monogr 56:73-96

Steneck RS (1983) Escalating herbivory and resulting adaptive trends in calcareous algae. Paleobiology 9:44-61

Steneck RS (1986) The ecology of coralline algal crusts: convergent patterns and adaptive strategies. Annu Rev Ecol Syst 17:273-303

Steneck RS, Paine RT (1986) Ecological and taxonomic studies of shallow-water encrusting Corallinaceae (Rhodophyta) of the boreal northeastern Pacific. Phycologia 25: 221-240

Underwood AJ (1997) Experiments in ecology: their logical design and interpretation using analysis of variance. Cambridge University Press, Cambridge

Underwood AJ (2006) Why overgrowth of intertidal encrusting algae does not always cause competitive exclusion. J Exp Mar Biol Ecol 330:448-454

Wetherbee R (1979) 'Transfer connections': specialized pathways for nutrient translocation in a red alga? Nature 204: 858-859

Winer BJ, Brown DR, Michels KM (1991) Statistical principles in experimental design. McGraw-Hill, New York

Submitted: October 25, 2005; Accepted: February 27, 2006

Proofs received from author(s): August 14, 2006 